\title{
In vitro Antagonism of Strains of Trichoderma spp., on Pathogenic Fungi of Nopal Vegetable
}

\author{
Ma. Angeles Valencia de $\operatorname{Ita}^{1}{ }^{(D)}$, Conrado Parraguirre Lezama ${ }^{1}$, \\ Alfredo Baez Simon ${ }^{1}$ (D) Luis A. Morales Mora ${ }^{1}$ (D), Manuel Huerta Lara² ${ }^{\mathbb{D}}$, \\ Beatriz Laug Garcia ${ }^{3}$ (D) and Omar Romero-Arenas ${ }^{1 *}$ (D) \\ ${ }^{1}$ Centro de Agroecologia, ICUAP, Benemerita Universidad Autonoma de Puebla (BUAP), Mexico. \\ ${ }^{2}$ Departamento de Desarrollo Sustentable, Instituto de Ciencias, BUAP, Mexico. ${ }^{3}$ Centro de Quimica- ICUAP- \\ BUAP, Mexico.
}

\begin{abstract}
In vitro antagonistic effect of different strains of 4 Trichoderma sp. namely $T$. harzianum, $T$. viride and T. atroviride and T. hamatum were evaluated against pathogenic fungi isolated from Nopal vegetable crops in San Sebastian Villanueva region Puebla, Mexico. The pathogenic fungi were Pythium sp., Fusarium sp. and Colletotrichum sp. Present investigation revealed T. harzianum inhibited maximum 73.7 and $68 \%$ radial growth of Fusarium sp. and on Colletotrichum sp. Trichoderma hamatum inhibited maximum 71.6 and $73.8 \%$ radial growth of Colletotrichum sp. and Pythium sp., respectively.

Keywords: Biological control, fungal diseases, Opuntia sp.
\end{abstract}

\footnotetext{
*Correspondence: biol.ora@hotmail.com

(Received: April 19, 2020; accepted: 13 May, 2020)

Citation: de Ita MAV, Lezama CP, Simon AB, et al. In vitro Antagonism of Strains of Trichoderma spp., on Pathogenic Fungi of Nopal Vegetable. J Pure App/ Microbiol. 2020;14(2):1345-1352. doi: 10.22207/JPAM.14.2.31

(C) The Author(s) 2020. Open Access. This article is distributed under the terms of the Creative Commons Attribution 4.0 International License which permits unrestricted use, sharing, distribution, and reproduction in any medium, provided you give appropriate credit to the original author(s) and the source, provide a link to the Creative Commons license, and indicate if changes were made.
} 


\section{INTRODUCTION}

The Nopal vegetable Opuntia ficus-indica

(L.) Miller (Caryophyllales: Cactaceae) in Mexico is one of the foods with the highest consumption, so its production has increased; going from 723 thousand tons produced in 2013 to 853 tons in 2018 in an area of $21,163,051.24$ hectares, leaving an economic spill of $\$ 27,392,486.24$ per year. Puebla occupies the fourth place in prickly Nopal vegetable production, with a production of 31,924.05 tons, the municipality of Acatzingo being one of the main producers with 9,344.50 tons, leaving an economic spill of $\$ 20,199.09$ by the end of $2018^{1}$.

Prickly Nopal vegetable cultivation has represented a productive; because it does not need large amounts of water and can thrive on marginal land or thrive in conditions where other traditional crops could not ${ }^{2,3}$. Productivity is reduced by several factors, among which are phytopathogenic diseases, mainly caused by Colletotrichum gloeosporioides, Pythium sp. and Fusarium solani ${ }^{4}$. The growing global concern about the damages caused by the excessive use of synthetic pesticides in human health, the environment, biodiversity and food security, has led to a general rejection of chemical control in agricultural production ${ }^{5}$. The Food and Agriculture Organization of the United Nations ${ }^{6}$ reported that in 2013 global agricultural production of 23.34 trillion tons was obtained; For which 1.29 million tons of pesticides (insecticides, herbicides, fungicides and bactericides) were applied. In Mexico, it is estimated that in 2007, 100,000 tons of these compounds were commercialized, equivalent to $4 \%$ of world consumption 7 .

The drawback of this type of control is highly related to the generation of resistance of phytopathogens ${ }^{8}$. Under this premise, alternatives are needed to decrease the damage caused by phytopathogenic fungi, therefore, biological control with antagonistic microorganisms has great potential ${ }^{9}$, since it is considered one of the most efficient and ecologically viable practices in the development of sustainable agriculture ${ }^{10}$.

The genus Trichoderma (Persoon) is the most relevant antagonist for the control of phytopathogenic fungi which are capable of controlling a large number of fungi that affect plants of agricultural interest ${ }^{9}$. The success and its use are due to mechanisms of action, such as competition, mycoparasitism, antibiosis and the production of volatile compounds that reduce the infection of causal agents in plants ${ }^{11}$. Trichoderma species have a high reproductive capacity and ecological plasticity coupled with the presence of microbial inhibitors, which give it great antagonistic activity $^{12}$. The Nopal is a vegetable that is mainly consumed fresh and it is necessary to obtain healthy and innocuous products, which is why an etiological determination is essential for good crop management. Consequently, the objective of this work was to determine the antagonistic capacity and the percentage of inhibition of the radial growth in vitro of 4 strains of Trichoderma spp., on fungal isolates of the Nopal vegetable crop in San Sebastian Villanueva, Acatzingo, Puebla-Mexico.

\section{MATERIALS AND METHODS Isolation zone}

The samples were collected in the months of May-June 2019, from commercial crops of prickly pear cactus on an area of $1,000 \mathrm{~m}^{2}$ with 5-year-old plants belonging to the community of San Sebastian Villanueva, municipality of Acatzingo Puebla-Mexico, located between the parallels $19^{\circ} 07^{\prime} 94^{\prime}$ 'north latitude and 97 $70^{\prime} 93^{\prime \prime}$ west longitude at a height of 2,400 masl. 16 transects of $10 \times 6 \mathrm{~m}$ were made on cladodes presenting symptoms of fungal diseases; of which $0.5 \mathrm{~cm}^{2}$ tissue were cut and placed in humid chambers then transfer to the laboratory. The samples with symptoms of fungal attack (phytopathogens) were disinfected with $1.5 \%$ sodium hypochlorite. These samples were washed three times with sterile distilled water, dried with sterile paper, $100 \mu \mathrm{L}$ of dilution $10^{6}$ were plated with antibiotic PDA agar (gentamicin $2 \mathrm{~mL} / \mathrm{Lt}$ ), pH 5.5 and incubated at $26 \pm$ $2^{\circ} \mathrm{C}$ for 7 days. Once the fungal colonies had grown, they were purified by tip hyphae ${ }^{13}$.

\section{Morphological characterization}

The generic identification of purified fungi from tissue was carried out by comparing the morphological characteristics of the colony and the type of structures with taxonomic identification keys $^{14}$, in a microculture system using an optical microscope (Carl Zeiss, Jena, Germany) at 1,000x magnifications. The colonies of the different fungi characterized in PDA plates (Agar-Papa-Dextrose, Bioxon ${ }^{\mathrm{TM}}$ ) were used to evaluate growth and 
development rate using the formula TD = VCF-VCI / Number of days; measuring the diameter in $\mathrm{mm}$ of the colonies every 24 hours for 10 days $^{9}$.

Evaluation of the antagonism of 4 strains of Trichoderma spp., against phytopathogenic fungi

The evaluation of the antagonism of 4

different Trichoderma strains with 3 repeats each, of which the T. hamatum strain SAH3, was used as a control and the variables to measure where the development rate and the antagonistic capacity of the treatments on the isolated phytopathogenic fungi. The dual culture technique ${ }^{8}$ was used, whereby, for each treatment, a $5 \mathrm{~mm}$ diameter disk with active mycelium of 8-day old fungal colonies of selected pathogenic fungus were deposited in one end of Petri dishes with PDA and allowed to develop for 3 days, for its slow growth. Subsequently, at the other end of the box, were deposited disks of $5 \mathrm{~mm}$ discs of the involved strains of Trichoderma spp., incubating at $25^{\circ} \mathrm{C}$ with a photoperiod of $12 \mathrm{~h}$ and $40 \%$ relative humidity. Mushroom growth readings were taken every $24 \mathrm{~h}$ with a Vernier; to determine the number of days at the first contact between the hyphae of the two fungi, the intersection zone after planting Trichoderma spp., with these data the "Percentage of inhibition of radial growth" was determined, applying the formula (PICR). To complement the evidence of antagonism, each trial was compared and classified in one of the 5 levels of the Bell scale ${ }^{15}$ (Table 1 ).

$$
\mathrm{PICR}=\frac{\mathrm{R} 1-\mathrm{R} 2}{\mathrm{R} 1}(100)
$$

Where:

R1: diameter of the control (average of the radial growth of the triplicates of each strain). R2: diameter of the tested organism.

\section{Biological material}

The evaluation of the antagonism was made with the TH-T4 strain of Trichoderma harzianum, TH-T3 Trichoderma viride, SAH3 Trichoderma hamatum, and TH-T1 of Trichoderma atroviride belonging to the Genetic Resources Center of the Agroecology Center of the Benemerita Universidad Autonoma de Puebla (BUAP).

\section{Statistical analysis}

Data were analyzed with ANOVA (twoway) in the IBM SPSS Statistics version 25 statistical package. Growth rate, development rate, and PICR were the response variables with three replications. The experiment was repeated twice for validation. A comparison of means was made by the Tukey-Kramer method with a probability level of $p \leq 0.05$.

\section{RESULTS AND DISCUSSION \\ Characterization of phytopathogens from the Nopal vegetable crop}

The pathogenic fungi were from infected plant tissues of the Nopal vegetable crop, from the municipality of Acatzingo Puebla-Mexico. The pathogenic fungi were Colletotrichum sp. (M7), Fusarium sp. (M4) and Pythium sp. (M6).

Among the main diseases caused by phytopathogenic fungi in the cultivation of prickly pear vegetables in the community of San Sebastian Villanueva, black spot is of greater importance, due to its high incidence during the production cycle as well as being favored by the presence of moisture and damage mechanical, as reported by MendezGallegos ${ }^{16}$, who mentioned that the presence of C. gloesporoides is associated with black spot in an advanced stage of the disease. The isolation of the phytopathogen was made in cladodes that had sunken black lesions, in a kind of concentric rings that developed in a limited area, these symptoms are currently described as anthracnose ${ }^{17}$.

Table 1. Bell ${ }^{15}$ antagonism scale

\begin{tabular}{ll} 
Class & \multicolumn{1}{c}{ Features } \\
\hline I & $\begin{array}{l}\text { Growth of Trichoderma sp., which covered the entire surface of the medium and reduced the pathogen } \\
\text { colony. }\end{array}$ \\
II & $\begin{array}{l}\text { Growth of Trichoderma sp., which covered at least } 2 / 3 \text { parts of the medium. } \\
\text { III }\end{array}$ \\
Trichoderma sp., and plant pathogen grew $1 / 2$ and $1 / 2$ the surface of the medium, one did not overlap \\
IV
\end{tabular}$\quad \begin{aligned} & \text { Pathogenic fungus grew at least } 2 / 3 \text { parts of the medium and resisted the invasion of Trichoderma sp. } \\
& \text { V }\end{aligned} \quad \begin{aligned} & \text { Growth of the pathogen that covered the entire surface of the medium. } \\
& \text { the }\end{aligned}$


The M7 strain presented radial colonies of gray color with a cottony appearance, septate mycelium, conidiomata, conidiophores and setae formed directly on hyphae. Conidia hyaline, smooth-walled, aseptate, the apex rounded, the base rounded to truncate, their size varies between 16-18 $\mu$ long and 3-4 $\mu$ wide ${ }^{18}$ (Fig. 1A). The morphological characteristics corresponding to Colletotrichum sp., Found in this work, are similar to those reported by Montero ${ }^{17}$. De la Torre ${ }^{23}$ quotes Colletotrichum sp. as a cause of anthracnose in the genus Opuntia. Quezada ${ }^{4}$ report as a saprophyte, taking advantage of the conditions set by Pseudocercospora sp. to develop in diseased tissue; However, in the isolates carried out in this work, this fungus was not found, being $C$. gloesporoides the one with the highest incidence in the cladode isolates that presented the black spot. Montero ${ }^{17}$, have reported that Fusarium sp. Along with the aforesaid fungi, it acts as a causal agent of this disease, causing stains and rots in the cladode tissue, contrasting with what was found in this research. Likewise, Villa ${ }^{19}$ reported Fusarium oxysporum causing root rot in most agricultural crops, initially penetrating the root asymptomatically and later colonizing vascular tissue and triggering massive wilt, necrosis and chlorosis of the aerial parts.

The M4 strain was characterized as a species belonging to the genus Fusarium. Fungal colonies developed abundant aerial mycelium, with a cottony texture and a white-pink color, and
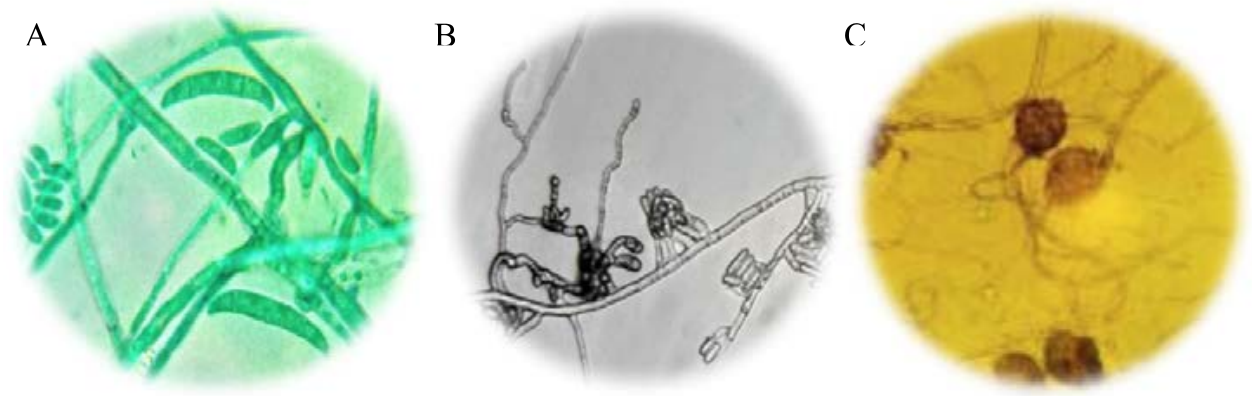

Fig. 1. (A) Macronidia of Fusarium sp., to 100X; (B) Conidiomas of Colletotrichum sp., to 100X; (C) Oogonia to Pythium sp., to $100 \mathrm{X}$.

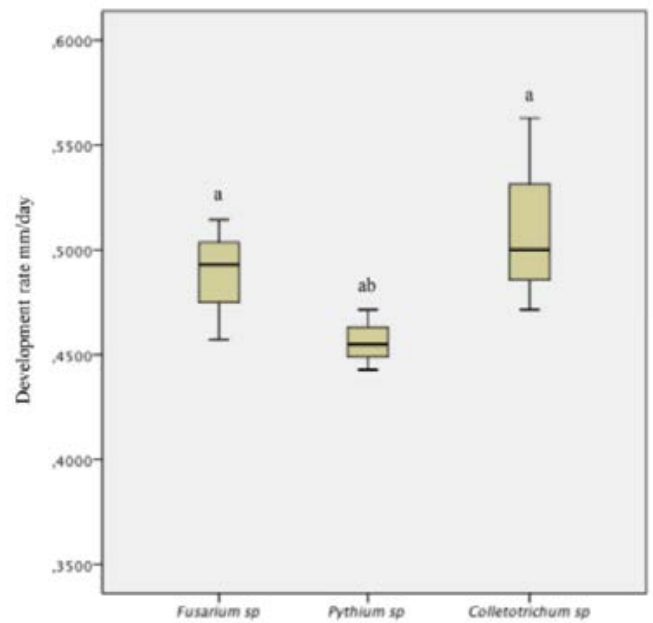

Fig. 2. Growth of fungi found in the Nopal vegetable crop.

* Different letters mean significant difference between treatments according to Tukey ( $p \leq 0.05)$. stained the agar with shades between purple and violet, aerial and abundant, fusiform macronidia with transverse concepts and ellipsoidal and piriform microconidia ${ }^{20}$ (Fig. 1B), can form masses (simulate heads) but never chains. In addition to macroconidia with the typical sickle or moon shape and have from one to five septa ${ }^{21}$.

The species of the genus Pythium are particularly destructive to the root system of some agricultural $\mathrm{crops}^{18}$, they produce a disease known as drowning and wilting (Damping off) in a large number of seedlings, and it also causes rotting of fruits and stems $\mathrm{s}^{22}$, in addition, it is associated with fungi of the genus Phytophthora and Fusarium ${ }^{18}$. Pythium sp., it was identified in this work, which is reported by De la Torre ${ }^{23}$, as a cause of rots in Opuntia sp. According to its macroscopic and microscopic characteristics, two different species 
were found of this pathogen, and it is convenient to carry out a molecular identification.

The M6 strain was characterized as a species belonging to the Pythium genus. It presented thin whitish hyphae with a tree-like upward growth, white-black mycelium, aerial and abundant. Oogonia equinulate and reticulatedwalled (Fig. 1C); asexual reproduction structures that are represented by zoospores that produce intercalary zoosporangia.

\section{Phytopathogen development rate}

According to the analysis of variance, a significant difference is found between the growth rate of the different fungi, for which one isolate represented a higher development rate compared to the rest (Fig. 2). Of the isolated phytopathogenic fungi, Colletotrichum sp., was the one that presented a higher rate of development with an average of $51 \mathrm{~mm} /$ day in PDA culture medium, a value that is similar to that quoted by Rojas $^{24}$ in his research, where C. gloesporoides under a range of $25-30^{\circ} \mathrm{C}$ it grew between 44 and $53 \mathrm{~mm} /$ day. This result showed to be high compared to that reported by Morales ${ }^{25}$, where C. gloesporoides under conditions similar to those of this experiment had a maximum growth of 24 $\mathrm{mm} /$ day, similar to that reported by Montero ${ }^{17}$, who mentions a growth rate between 24 and 31 $\mathrm{mm} /$ day. However, Akhter ${ }^{26}$ reports a radial growth of $63 \mathrm{~mm} /$ day, being greater than what was found in this investigation.

For Fusarium sp. the growth was 48 $\mathrm{mm} /$ day, which differs from that reported by other authors, where Fusarium sp. it presents between 70 and $73 \mathrm{~mm} /$ day in PDA $^{27}$, unlike what was mentioned by Neagu and Borda ${ }^{28}$, where in barley and rice media it grows up to 98 and 99 $\mathrm{mm} /$ day. For sample M6 (Pythium sp) $40 \mathrm{~mm} /$ day, representing the lowest growth values of the total isolated fungi. Colletotrichum sp., grows faster compared to the other isolated fungi, which shows its greater aggressiveness and this can also explain the higher frequency of isolated colonies as well as the highest incidence in the field.

Antagonistic capacity of strains of Trichoderma spp. on nopal vegetable culture phytopathogens

In the present investigation, the Trichoderma species used showed various degrees of inhibition on the isolated fungi. The criterion for selecting the best strains was considering the highest percentage of inhibition, which varied from 8 to $73.8 \%$ (Fig. 3), so that the strains corresponding to T. harzianum and SAH3 (T. hamatum) which served as control, are those that showed the best results according to the Tukey test $(p<0.05)$. Inhibition of radial growth in dual culture is attributed to substances released by one or both organisms or by competition ${ }^{29}$.

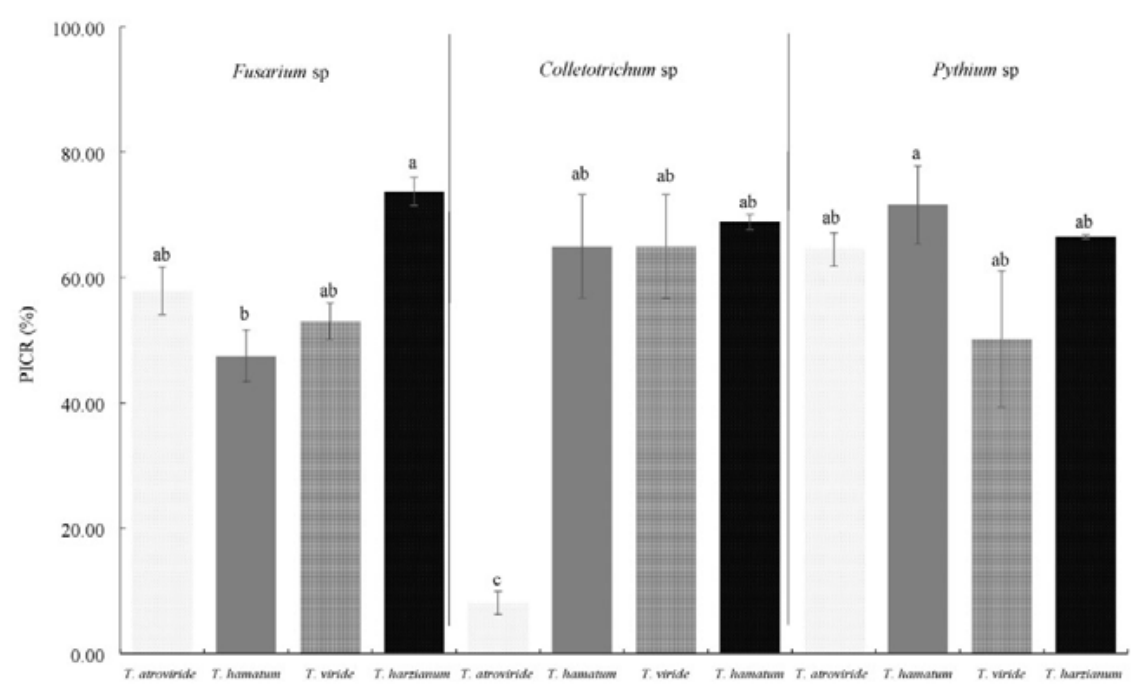

Fig. 3. Percentage of inhibition (PICR) of Trichoderma strains on phytopathogenic fungi of the Nopal vegetable culture in vitro.

* Different letters mean significant difference between treatments according to Tukey ( $p \leq 0.05)$. 
The parasitic action exerted by one fungus on another is called hyperparasitism, this is because some fungi produce cellulases and antibiotics and can metabolize chitin; Tapwal ${ }^{29}$ report than $T$. harzianum, T. viride and $T$. malignorum, as biological control agents on phytopathogenic fungi such as $R$. solani, Pythium sp., Fusarium spp., Alternaria spp., C. gloesporoides, Rhizopus arrhizus, Rhizovtonia endophytica and other pathogenic fungi that reduce agricultural production.

The SAH3 strain had the highest inhibition values with 73.8 and $71.6 \%$ over the Pythium sp. T. harzianum stopped the growth of Fusarium sp., by $73.7 \%$ and Colletotrichum sp., by $68.9 \%$. The strain with the lowest inhibition value was $T$. atroviride on Colletotrichum sp., with $8 \%$.

Some authors cite $T$. harzianum and $T$. viride with potential for the control of fung of the genera Pythium and Fusarium in various agricultural $\mathrm{crops}^{30,31}$, in the case of the present work, the Trichoderma strains exerted a percentage of inhibition greater than $50 \%$ for Pythium and Fusarium, except for T. hamatum, whose value was lower.

The values of $T$. harzianum, $T$. viride and $T$. atroviride with the exception of $T$. hamatum had values above $50 \%$ on Fusarium sp., this is similar to that reported by Sundaramoorthy and Balabaskar ${ }^{32}$, who mention $T$. harzianum with potential for the biocontrol of $F$. oxysporum in tomato, by inhibiting it's in vitro growth by $53 \%$. The results of this investigation are high compared to that reported by Sierra ${ }^{33}$ for $F$. subglutinans, where the highest percentages are in correspondence with $T$. atroviride with $48 \%$.

According to the classification of Bell ${ }^{15}$ antagonisms at 7 days of observation, the isolates were located between classes I, II and III. Most of them remained under scale I were
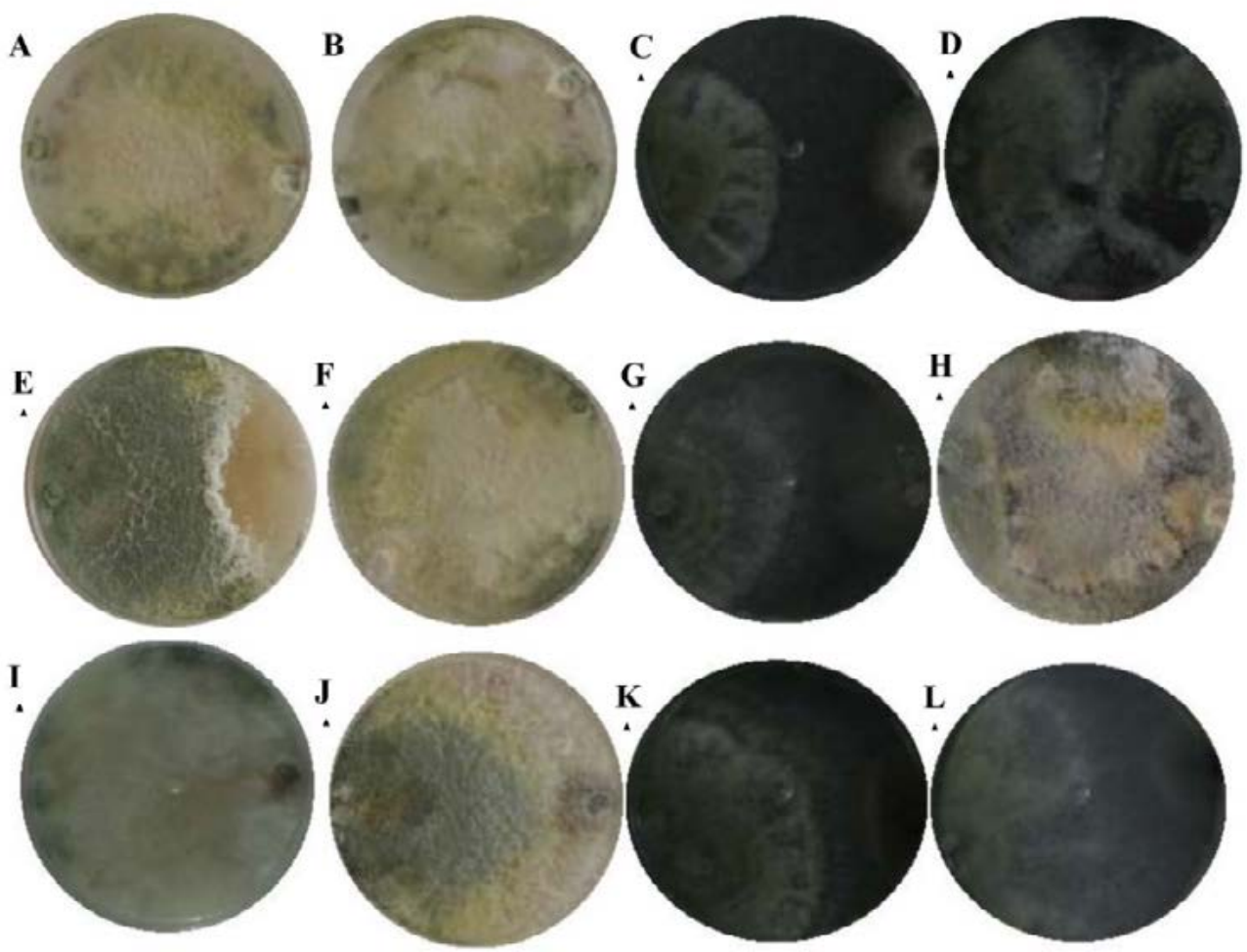

Fig. 4. Bell ${ }^{15}$ scale at 7 days of observation; T. hamatum presented a type II antagonism against Colletotrichum sp. (A), type I in Fusarium sp. (E) and Pythium sp. (I); T. harzianum, presented a type I antagonism against Colletotrichum (B), Fusarium sp. (F) and Pythium sp. (J); T. viride, I present a type II antagonism against Colletotrichum sp. (C), Fusarium sp. (G) and Pythium sp. (K) and T. atroviride, I present a type III antagonism against Colletotrichum sp. (D), type I for Fusarium sp. (H) and Pythium sp. (L). 
Trichoderma inhibited the total growth of the phytopathogens, such as T. harzianum case. The strain of $T$. atroviride had the lowest percentage of inhibition on Colletotrichum sp., Remaining on scale III, where both strains were developed in $50 \%$ of the culture media (Fig. 4).

Rodriguez and Veneros ${ }^{34}$ pointed out that $T$. harzianum showed class 2 antagonistic capacity according to the Bell scale on isolated fungi of $C$. gloesporoides, Stemphylium lycopersici, F. oxysporum, A. alternata, indicating that the antagonist invaded $1 / 2$ of the surface of the colony of the pathogenic fungus, similar results in the present investigation. Reyes ${ }^{35}$ reported that one of the significant characteristics of the genus Trichoderma is its high growth rate, which gives it the possibility of being a good competitor for space and nutrients, fundamentally, in vitro conditions against pathogens that cause plant diseases.

\section{CONCLUSION}

Three pathogens were identified in the nopal vegetable crop, being Colletotrichum sp. the most representative in San Sebastian Villanueva, Puebla, followed to a lesser extent by Fusarium sp. and Pythium sp.

The strains of the species $T$. harzianum and T. hamatum showed the highest percentage of inhibition (70\%) which represents a potential in biological control of the phytopathogens found in the community of San Sebastian Villanueva, municipality of Acatzingo Puebla-Mexico.

The analyzes of antagonism tests through in vitro bioassays, constitute an important parameter to know the competitive capacity of the species in relation to the phytopathogenic fungi and to establish a selection strategy for their control.

\section{ACKNOWLEDGMENTS}

The authors thank the Vicerrectoria de Investigacion y Estudios de Posgrado (VIEP) of the Benemerita Universidad Autonoma de Puebla (BUAP) for the financial support for this research, as well as CONACYT for the support received.

\section{CONFLICT OF INTEREST}

The authors declare that there is no conflicts of interest.

\section{AUTHORS' CONTRIBUTION}

All authors listed have made a substantial, direct and intellectual contribution to the work, and approved it for publication.

\section{FUNDING}

The authors thank the Vicerrectoria de Investigacion y Estudios de Posgrado (VIEP) of the Benemerita Universidad Autonoma de Puebla (BUAP), for the financial support for this research project, for the support received for the project "ID: 100420500".

\section{ETHICS STATEMENT}

This article does not contain any studies with human participants or animals performed by any of the authors.

\section{DATA AVAILABILITY}

All datasets generated or analyzed during this study are included in the manuscript and/or the Supplementary Files.

\section{REFERENCES}

1. Servicio de Informacion Agroalimentaria y Pesquera (SIAP) 2018. Atlas Agroalimentario, 2012-2018.

2. Ochoa JM. Mancha negra: una importante enfermedad en plantaciones para fruto, forraje y Nopalitos. Cactusnet Newsletter. 2012;13:63-73.

3. Moctezuma LG. Innovaciones tecnologicas en la cadena agroproductiva Nopal (Opuntia spp) en la ciudad de Mexico por medio del programa extensionismo. Revista de Agronegocios. 2019;23(45):299-312.

4. Quezada SA, Sandoval IJS, Alvarado RD, Moreno V. Histopatologia y patogenesis de Pseudocercospora opuntiae en Nopal. Revista Mexicana de micologia. 2013;38:9-18.

5. Ibrahim YA. Health and environmental impacts of pesticides: A responsibility principle and two novel systems for hazard classification and external cost determination. Journal of Toxicology and Healt. 2016;3(1):1-9. https://doi.org/10.7243/2056-3779-3-1 FAO. 2015. FAOSTAT.

7. FAO. 2017. FAOSTAT.

8. Andrade-Hoyos P, Luna-Cruz A, Hernandez EO, Gayosso EM, Valenzuela NL, Cureno HJB. Antagonismo de Trichoderma spp. vs hongos asociados a la marchitez de chile. Revista Mexicana de Ciencias Agricolas. 2019;10(6):1259-1272. https://doi.org/10.29312/ remexca.v10i6.1326

9. Romero-Arenas O, Amaro LJ, Damian HM, Valencia de Ita MA, Rivera A, Huerta L. Biopreparados de Trichoderma spp. para el control biologico de Phytophthora capsici en el cultivo de tomate de Puebla, Mexico. ITEA. 2017;113(4):313-324. https:// doi.org/10.12706/itea.2017.019 
10. Perez-Torres E, Bernal-Cabrera A, Milanes-Virelles $P$, et al. Eficiencia de Trichoderma harzianum (cepa a-34) y sus filtrados en el control de tres enfermedades fungicas foliares en arroz. Bioagro. 2018;30(1):17-26.

11. Hernandez-Melchor DJ, Ferrera-Cerrato R, Alarcon A. Trichoderma: importancia agricola, biotecnologica, y sistemas de fermentacion para producir biomasa y enzimas de interes industrial. Chilean Journal of Agricultural And Animal Sciences. 2019;35(1):98-112. https://doi.org/10.4067/S0719-38902019005000205

12. Harman GE. Myths and dogmas of biocontrol: changes in perceptions derived from research on Trichoderma harzianum T-22. Plant Disease. 2000;7:377-393. https://doi.org/10.1094/PDIS.2000.84.4.377

13. Villanueva-Arce R, Aguilar-Pompa CA, Toro VD, PinaGuzman A, Bautista-Banos S. Control de bacterias patogenas y hongos de postcosecha con extractos del pigmento de Gibberella zeae (Fusarium graminearum). Agrociencia. 2013;47(7):691-705.

14. Barnett HL, Hunter BB. Illustrated genera of imperfect fungi. St. Paul, Minnesota, USA: The American Phytopathological Society, 1998.

15. Bell DK, Wells HD, Markham C. In vitro antagonism of Trichoderma species against six fungal plant pathogens. Phytopathology. 1982;72:379-382. https:// doi.org/10.1094/Phyto-72-379

16. Mendez-Gallegos SJ, Talavera-Magana D, GarciaHerrera E. Identificacion y control de las principales enfermedades del Nopal. Revista Saludo Publica y Nutricion. 2008;14:105-113.

17. Montero TV, Morales GJL, Gonzalez CMM, Anaya LL, Corona TT, Galvez M. Diversidad genetica, patogenica y morfologica del hongo Colletotrichum gloesporoides (Penz.) de Michoacan, Mexico. Revista Mexicana de Ciencias Agricolas. 2010;1:159-174.

18. Hawksworth DL, Kirk PM, Sutton BC, Pegler DM. Ainsworth and Bisby's dictionary of the fungi. 8th edition. CAB International, Wallingford. 1995.

19. Villa MA, Perez LR, Morales MH, Basurto SM, Soto PJM, Martinez E. Situacion actual en el control de Fusarium spp. y evaluacion de la actividad antifungica de extractos vegetales. Acta agronomica. 2014;64:194205. https://doi.org/10.15446/acag.v64n2.43358

20. Renteria-Martinez ME, Guerra-Camacho MA, OchoaMeza A, et al. Multilocus phylogenetic analysis of fungal complex associated with root rot watermelon in Sonora, Mexico. Mexican Journal of Phytopatholgy. 2018;36(2):233-255. https://doi.org/10.18781/R.MEX. FIT.1710-1

21. Gordon TR. Fusarium oxysporum and the Fusarium wilt syndrome. Annu Rev Phytopathol. 2017;55:23-39. https://doi.org/10.1146/annurevphyto-080615-095919

22. Uzuhashi S, Tojo M, Kakishima M. Phylogeny of the genus Pythium and description of new genera. Mycoscience. 2010;51:337-365.
23. De la Torre AR. Inventario fitopatologico de las especies vegetales dominantes en la region de Zapotitlan de Salinas, Pue. CONABIO, 2001;69.

24. Rojas EI, Rehner SA, Samuels GJ, et al. Colletotrichum gloesporoides s.l. associated with Theobroma cacao and other plants in Panama: multilocus phylogenies distinguish host-associated pathogens from asymptomatic endophytes. Mycologia. 2010;102:1318-1338. https://doi.org/10.3852/09-244

25. Morales GJL, Rodriguez GMP, Azpiroz RHS, Pedraza S.M. Temperatura base in vitro de Colletotrichum gloesporoides Penz. Aislado de frutos de aguacate (Persea americana Mill.) cv. Hass en Michoacan, Mexico. Revista UDO Agricola. 2009;9:414-420.

26. Akhter S, Alam S, Islam S, Woong L. Identification of the fungal pathogen that causes strawberry anthracnose in Bangladesh and evaluation of in vitro fungicide activity. Mycobiology. 2009;37:77-81.

27. Gupta VK, Misra AK, Gaur K. Growth characteristics of Fusarium spp. causing wilt disease in Psidium guajava L. in India. Journal of Plant Protection Research. 2010;50:452-462. https://doi.org/10.2478/v10045010-0076-3

28. Neagu C, Borda D. Modelling the groth of Fusarium graminearum on barley and wheat media extract. om Biotechnol Lett. 2013;18(4):8489-8498.

29. Tapwal A, Thakur G, Chandra S, Tyiagi A. In vitro evaluation of Trichoderma species against seed borne pathogens. International Journal of Chemical and Biological Sciences. 2015;1:14-19.

30. Bae YS, Knudsen R. Soil microbial biomass influence on growth and biocontrol efficacy of Trichoderma harzianum. Biological Control. 2005;32:236-242. https://doi.org/10.1016/j.biocontrol.2004.10.001

31. Verma M, Brar KS, Tyagi DR, Surampalli R, Valero J. Antagonistic fungi, Trichoderma spp.: Panoply of biological control. Chem Eng J. 2007;37:1-20. https:// doi.org/10.1016/j.bej.2007.05.012

32. Sundaramoorthy S, Balabaskar P. Biocontrol efficacy of Trichoderma spp. against wilt tomato caused by Fusarium oxysporum f. sp. Lycopersici. J Appl Biol Biotechnol. 2013;1:36-40.

33. Sierra PA, Hernandez MA, Diaz AJ, Carr P. Control in vitro con Trichoderma spp. de hongos fitopatogenos de vitroplantas de pina (Ananas comosus (L) Merr.). Centro Agricola. 2007;34:19-23.

34. Rodriguez LM, Veneros T. Control biologico de Trichoderma harzianum RIFAl. sobre hongos patogenos de frutos postcosecha de Carica papaya procedente de zonas de distribucion del distrito Trujillo (Peru). Revista de la Facultad de Ciencias Biologicas. 2011;31:1-9.

35. Reyes $Y$, Martinez B, Infante D. Evaluacion de la actividad antagonica de trece aislamientos de Trichoderma spp. sobre Rhizoctonia sp. Revista de Proteccion Vegetal. 2008;23(2):112-117. 